\title{
Samed Behrengi'nin Sevgi Masalı, Bir Şeftali Bin Şeftali ve Kel Güvercinci Adlı Öykülerinin Kök Değerler Açısından İncelenmesi
}

\author{
An Investigation of Samed Behrengi's Three \\ Works: Tale of Love, One Peach Thousand Peaches \\ and Bald Pigeon in Terms of Root Values
}

\author{
Mehrali CALP, Sorumlu Yazar, Doç.Dr. \\ Ağrı İbrahim Çeçen Üniversitesi, Eğitim Fakültesi, Ağrı / Türkiye. \\ mcalp@agri.edu.tr \\ https://orcid.org/0000-0002-2261-4893
}

Cezmi KAPLAN, Öğretmen

T.C. Milli Eğitim Bakanlığı, Bitlis / Türkiye

cezmikaplan13@hotmail.com

https://orcid.org/0000-0003-1355-6035

\author{
ISSN: 1303-880X \\ e-ISSN: 2667-7504 \\ http://ded.dem.org.tr
}

Makale Türü / Article Type:

Araştırma Makalesi / Research Article

Geliş Tarihi / Received Date: 07.04.2021

Kabul Tarihi / Accepted Date: 12.12.2021

Yayın Tarihi / Published Date: 25.12.2021

Tr/En: $\operatorname{Tr}$

Intihal / Plagiarism: Bu makale, en az iki hakem tarafindan incelendi ve intihal içermediği teyit edildi. / This article has been reviewed by at least two referees and scanned via a plagiarism software.
Attf/Citation: Calp, M. \& Kaplan, C. (2021). Samed Behrengi'nin Sevgi Masalı, Bir Şeftali Bin Şeftali ve Kel Güvercinci adlı öykülerinin kök değerler açısından incelenmesi. Değerler Eğitimi Dergisi, 19 (42), s. 39-72 https://doi.org/10.34234/ded.910908 
Öz: Eğitim ve öğretim çalışmalarının bilgi kazandırmak, meslek edindirmek gibi amaçlarının yanında olumlu davranış ve değer kazandırma gibi amaçları da bulunmaktadır. Toplumun geleceğini yakından ilgilendiren millî ve evrensel değerlerin yetişen kuşaklara kazandırılması ve onlar tarafından özümsenmesi önemlidir. Bu araştırmanın amacı, Samed Behrengi’nin "Sevgi Masalı", "Bir Şeftali Bin Şeftali” ve "Kel Güvercinci” öykülerini 2019 Türkçe Dersi Öğretim Programı'nda yer alan on kök değer (adalet, sevgi, dostluk, dürüstlük, öz denetim, sabır, saygı, sorumluluk, vatanseverlik, yardımseverlik) açısından incelemektir. Nitel araştırma yönteminin kullanıldığı bu araştırmada, veri toplama aracı olarak doküman incelemesi tekniğine başvurulmuştur. Öykülerde bulunan değerler sınıflandırılmış ve sıklık analizi yapılmıştır. Araştırmada "Bir Şeftali Bin Şeftali" adlı öyküde sevgi, sabır, adalet, dostluk, yardımseverlik, sorumluluk; "Sevgi Masalı"nda adalet, dürüstlük, sevgi, sorumluluk, sabır; "Kel Güvercinci" de ise sevgi, adalet, yardımseverlik, sorumluluk, dürüstlük değerlerine yer verildiği ve bu öykülerin, kök değerlerin aktarımında yararlı bir eğitim arac1 olarak kullanılabileceği sonucuna varılmıştır.

Anahtar Kelimeler: Bir Şeftali Bin Şeftali, Değerler Eğitimi, Kök Değer, Sevgi Masal, Samed Behrengi.

\section{$\&$}

Abstract: Education and training studies have purposes such as delivering knowledge and profession, as well as equipping positive behavior and value. It is critical that national and universal values, which are of utmost importance for the future of society, are transferred to the next generations. The purpose of this research is to analyze Samed Behrengi's "Tale of Love", "One Peach Thousand Peach" and "Bald Pigeon" stories with ten root values (justice, love, friendship, honesty, self-control, patience, respect, responsibility, patriotism, benevolence) in the 2019 Turkish Course Curriculum. In this study, in which qualitative research method was used, document analysis technique was used as a data collection tool. Values found in the stories were classified and frequency analysis was performed. Value of; love, patience, justice, friendship, benevolence, responsibility; Justice, honesty, love, responsibility, patience are found to be employed in "Tale of Love"; on the other hand, it has been found that the value of love, justice, benevolence, responsibility and honesty are included in "Bald Pigeon" while love, justice, benevolence, responsibility and honesty are found in the story of "One Peach Thousand Peach", thus these stories are considered as a useful educational tool in the transfer of root values. 
Keywords: One Peach Thousand Peaches, Values Education, Root Value, Tale of Love, Samed Behrengi.

(The Extended Abstract is at the end of the article)

\section{Giriş}

Hızla gelişen ve değişen dünyada eğitimin amacı sadece akademik bilgi ve beceri aktarmak olmamalıdır. Eğitim, aile ortamında başlayıp okul çatısı altında devam eden ve insanları hayata hazırlayan önemli bir süreçtir. Eğitim sözcügü̈, Türkçe Sözlük’te (TDK, 2005) çocukların ve gençlerin toplum yaşayışında yerlerini almaları için gerekli bilgi, beceri ve anlayışları elde etmelerine, kişiliklerini geliştirmelerine okul içinde veya dışında, doğrudan veya dolaylı yardım etme, terbiye; şeklinde tanımlanmıştır. Bilişsel alanda donanımlı bireyler yetiştirmek eğitimin temel hedeflerinden biri olsa da toplumsal birlikteliği sağlayan ve toplumu ayakta tutan kültürün gelecek nesillere aktarılmasına hizmet eden değerlerin eğitimi de eğitimin hedeflerindendir. Değerler, insanın hayatını anlamlı kılan ve insanı harekete geçiren önemli enerji kaynaklarıdır. Değerler, kültür öğeleri üzerine kuruldukları için nesilden nesile kültür yoluyla aktarılarak birbirlerinin devamlılıklarını sağlarlar (Akbaba Altun, 2003). Toplumu meydana getiren, bireylerin sağlıklı bir gelecek için sahip olmaları gerektiği kabul edilen duygu, davranış ve kurallar olan değerler, bireylerin insani yönlerinin ve algılarının gelişimini büyük ölçüde etkilemektedir (Ulusoy ve Dilmaç, 2016). Bu nedenle eğitim kurumları, bireye akademik başarı katma yanında bireyin sağlıklı bir kişiliğe sahip olması ve toplumsal değerlere uyum sağlaması için de çaba harcamalıdır.

Sözlüklerde arzu uyandıran, ilgi duyulduğu için takip edilen, ayarlama ölçütü olarak kullanılan şey anlamlarına gelen değer, Latince "kıymetli olmak", "güçlü olmak" anlamlarında kullanılan "valere" kökünden türemiştir (Aydın, 2011). TDK (2020) sözlüğünde ise değer kavramı "bir şeyin önemini belirlemeye yarayan soyut ölçü, bir şeyin değdiği karşıllk, kıymet; üstün nitelik, meziyet, yararlı nitelikleri olan kimse. Bir ulusun sahip olduğu sosyal, kültürel, ekonomik ve bilimsel değerlerini kapsayan maddi ve manevi ögelerin bütünü." şeklinde tanımlanmıştır. Yapılan tanımların ortak noktaları doğrultusunda değer kavramını; kişinin davranış, duygu ve düşüncelerini yönlendiren güzellik ve iyilik standartları şeklinde tanımlamak mümkündür.

Millî Eğitim Bakanlığı tarafından 2017 yılının temmuz ayında yapılan basın açıklamasıyla mevcut müfredatların, öğrenme öğretme teori ve yaklaşımların- 
daki yenilik ve gelişmeler doğrultusunda çağın gerekliliklerini, ferdin ve toplumun değişen ihtiyaçlarını karşılayacak şekilde yenilendiği belirtilmiştir (TTKB, 2017). Yenilenen öğretim programları incelendiğinde göze çarpan değişikliklerin başında "kök değer" kavramının geldiği görülmektedir. 18 Temmuz 2017 tarihinde "Müfredatta Yenileme ve Değişiklik Çalışmalarımız Üzerine" başl1ğıyla yayınlanan bu bildiride değerler eğitimine ilişkin "on kök değer"den bahsedilmiştir. Bu değerler: "adalet, dostluk, dürüstlük, öz denetim, sabır, sayg1, sevgi, sorumluluk, vatanseverlik ve yardımseverlik" olarak sunulmuştur.

Günümüz eğitim programlarının amacı akademik yönden başarılı ve temel değerleri özümsemiş bireyler yetiştirmektir (Ekşi, 2003). Alimcan ve Şam (2017)'a göre değerler eğitimini kısaca "değer kazandırma etkinliği” olarak tanımlamak mümkündür; çünkü değerler, öğrenilebilen ve öğretilebilen edinimlerdir. Gözlem ve etkileşim yoluyla yaşayarak öğrenilen değerlere insanoğlu doğuştan sahip değildir (Bostrom, 1991; Akt. Akbaş, 2004). Değerlerin edinilmesinde eğitim kurumlarının, ailenin, sosyal ve yakın çevrenin önemli görevleri bulunmaktadır (Baki, 2019). Aile, çocuğun hayata dair temel davranış ve becerileri edindiği ilk kurumdur. Çocukların hayata hazırlanmasından ve eğitilmesinden birinci derece sorumlu olan aileler, çocuklarının maddi-manevi ihtiyaçlarını karşılamalı ve onların sosyalleşmesine yardımcı olmalıdır (Aktepe, 2016). Aile ortamı çocuğun sosyalleşmesine katkı sağlayan bir duraktır. Burada öğrenilen değerler çocukların topluma uyum sağlamalarına yardımcı olmaktadır. Her toplumun kendine göre değer yargıları ve ahlaki kuralları vardır. Toplum için değerler öylesine önemlidir ki değerlere uygun davranışlar içinde olan insanlar toplum tarafından değerli kabul edilir (Aslan, 2019). Değeredindirme sürecinde eğitim kurumlarına büyük sorumluluklar düşmektedir. Örgün eğitimin planlı ve programlı bir şekilde yapıldığı yer olan okullar, yeni nesillere değer aktarımı için en uygun alanlar kabul edilir. Millî Eğitim Temel Kanununun (1973) öğretim programlarına yansıyan,

Beden, zihin, ahlâk, ruh ve duygu bakımlarından dengeli ve sağlıklı şekilde gelişmiş bir kişiliğe ve karaktere, hür ve bilimsel düşünme gücüne, geniş bir dünya görüşüne sahip, insan haklarına saygılı, kişilik ve teşebbüse değer veren, topluma karşı sorumluluk duyan, yapıcı, yaratıcı ve verimli kişiler olarak yetiştirmek, şeklindeki genel hedefi de okulların bu konudaki sorumluluğuna işaret etmektedir. Ayrıca, Millî Eğitim Değerler Eğitimi Yönergesi'ndeki (2015) “Öğrencilere temel insanî değer ve erdemleri kazandırma, değerlere karşı duyarlılık oluşturma ve onları davranışa dönüştürme konusunda yardımcı olmak" amacı, 
eğitim kurumlarının işlevine yönelik bir amaçtır. Değerler eğitiminin bir diğer amacı olan, "öğrencilerde sağlıklı, tutarlı ve dengeli bir kişilik oluşumuna yardımcı olmaktır." amacı, aslında eğitimin en temel amacıdır; çünkü bu amaç olmadan, belirlenmiş diğer amaçlara ulaşılsa da fazla bir anlam ifade etmez (Aydın, 2010). Öğrencilere aktarılan değerlerin kullanımında eğitim durumu, yaş, cinsiyet, aile, sosyal konum ve yaşanılan çevre gibi faktörler önemli etkenler arasında yer almaktadır.

Değer aktarımında çocuğun aile ortamı ve yakın çevresinden sonra eğitim ve öğretim programlarının planlayıcısı ve temel uygulayıcısı olan öğretmenlere büyük görevler düşmektedir (Karatay, 2007). Okul ortamında değerleri öğretebilmenin en iyi yolu önce o değerlere sahip olmak sonra da model olmakla mümkün olabileceği unutulmamalıdır (Kasapoğlu, 2013). Davranışlarıyla öğrencilerine model olan öğretmenler, öğrencilerine değerleri deneyim etme ve uygulama imkânı sağlamalıdır. Bu sayede değerler eğitimi daha kolay gerçekleşir.

Çocukların duygu ve düşünce dünyalarına seslenebilen bütün sözlü ve yazılı kaynaklar değerler eğitiminde kullanılabilir (Kasapoğlu, 2013). Değerler gözetilerek hazırlanmış, öğrencilerin yaş ve gelişim düzeyine uygun kitaplar, değer eğitimini olumlu yönde etkiler. Çocukları kendi dünyasına çekerek onlara bir takım yaşam tecrübeleri sunan edebi eserler, eğitim çağındaki çocukların bazı değerleri doğal bir şekilde edinmelerine yardımcı olur. Özellikle edebi eserlerdeki kahramanlar, çocukların rol model seçiminde önemli bir yere sahip iken edebi eserlerin hangi değerleri içerdiği de önem arz etmektedir (Gümüş, 2017). Dolayısıyla türü ne olursa olsun çocuk edebiyatı ürünlerinde işlenen konular, kişi kadroları ve kullanılan anlatım teknikleri; çocukların renkli ve masum dünyasını olumlu yönde geliştirmeli, onlara birtakım doğru davranış kalıplarını ve değerleri kazandırmaya yönelik olmalıdır (Arseven, 2005). Çocukluk dönemi kişilik gelişimi için oldukça önemli bir dönemdir. Bu dönemde çocuk kendisine bir rol ve model temsilcisi arar. Bu; bazen bir arkadaş, bazen bir öğretmen bazen de bir eser kahramanı olabilmektedir. Çocuklar bazen eser karakterleriyle birlikte yaşamın sorunlarıly yüzleşir ve onlara çözümler üretir. Bu sayede farkında bile olmadan toplumsal değerleri edinir. Bu nedenle çocuklara okutulacak kitaplar iyi seçilmelidir.

\section{Amaç}

Bu çalı̧̧manın amacı, Samed Behrengi'nin "Sevgi Masalı", "Bir Şeftali Bin Şeftali” ve "Kel Güvercinci” adlı öykülerini 2019 Türkçe Dersi Öğretim Programı'nda yer alan kök değerler bağlamında değerler eğitimi yönünden incelemektir. 
$\mathrm{Bu}$ amaç doğrultusunda çalışmada aşağıdaki sorulara cevap aranmıştır.

Samed Behrengi’nin "Sevgi Masalı” adlı öyküsünde, 2019 Türkçe Dersi Öğretim Programı'nda yer alan kök değerlerden hangileri ne sıklıkla yer almaktadir?

Samed Behrengi'nin "Bir Şeftali Bin Şeftali” adlı öyküsünde, 2019 Türkçe Dersi Öğretim Programı'nda yer alan kök değerlerden hangileri ne sıklıkla yer almaktadır?

Samed Behrengi'nin "Kel Güvercinci” adlı öyküsünde, 2019 Türkçe Dersi Öğretim Programı'nda yer alan kök değerlerden hangileri ne sıklıkla yer almaktadir?

\section{Yöntem}

\section{Araştırmanın Modeli}

$\mathrm{Bu}$ çalışmada nitel araştırma yöntemlerinden tarama modeli kullanılmıştır. Tarama modelleri, olayları veya durumları tanımlamak için tasarlanmış modellerdir. Konunun veya durumun tanımı kendi koşullarına ve mevcut durumuna bağlıdır (Karasar, 1998).

\section{Çalışma Materyali}

Araştırmanın nesnesini Samed Behrengi’nin "Sevgi Masalı", "Bir Şeftali Bin Şeftali” ve "Kel Güvercinci” öyküleri oluşturmaktadır. Samed Behrengi’nin yayımlanan toplam 17 öyküsü bulunmaktadır. Sanatkârın tüm eserleri bir bütünce (corpus) kabul edierek bu eserlerden sistematik örneklem yöntemiyle "Sevgi Masalı", "Bir Şeftali Bin Şeftali” ve "Kel Güvercinci” adlı öyküleri belirlenmiştir.

\section{Verilerin Toplanması}

Nitel araştırma yönteminin kullanıldığı bu araştırmada, veri toplama aracı olarak doküman incelemesi tekniğine başvurulmuştur. Bunun için literatür taraması kapsamında öncelikle Samed Behrengi tarafından kaleme alınan öyküler belirlenmiştir. Belirlenen bu öykülerin adları yazılarak sıra numarası verilip sistematik örneklem yöntemiyle aralarından 3 öykü belirlenmiştir. Bunlar:"Sevgi Masalı", "Bir Şeftali Bin Şeftali” ve "Kel Güvercinci” adlı öyküler olup Parıltı 
Yayınları'dan temin edilmiştir. Daha sonra araştırmaya konu olan kök değerler, değerler eğitimi, Türkçe dersi öğretim programları ile ilgili tezler, makaleler, süreli yayınlar ve kitaplar incelenmiştir.

Çalışma kapsamında Samed Behrengi'nin "Sevgi Masalı”, "Bir Şeftali Bin Şeftali" ve "Kel Güvercinci” adlı öyküleri araştırmacılar tarafından ayrı ayrı birkaç defa ayrıntılı okunmuştur. 2019 Türkçe Dersi Öğretim Programında yer alan

hakve hukuka uygunluk, hak gözetme (TDK, 2021) anlamına gelen adalet; "dost, sevilen, güvenilen, yakın arkadaş; gönüldaş, iyi görüşülen kimse, birbirini seven kişilerden her biri” olarak ele alınan (Albayrak, 2004) dostluk; doğruluk anlamındaki dürüstlük; "daha önemli bir amaca ulaşabilmek için kişinin tepkilerini, davranışlarını veya başka amaca yönelme eğilimini denetleyip kısıtlamas1, otokontrol" anlamına gelen (TDK, 2021) öz denetim; "sabreden, dayanan, acelesiz bekleyen, dişini sıkan" (Devellioğlu, 2005) anlamında kullanılan sabır; "değeri, üstünlüğü, yaşlılığı, yararlıllğı, kutsallığı dolayısıyla bir kimseye, bir şeye karşı dikkatli, özenli, ölçülü davranmaya sebep olan sevgi duygusu, hürmet, ihtiram" (TDK, 2021) anlamına gelen saygı; "insanı bir şeye veya bir kimseye karşı yakın ilgi ve bağl1lık göstermeye yönelten duygu” (TDK, 2021) olarak tanımlanan sevgi; "kişinin kendi davranışlarını veya kendi yetki alanına giren herhangi bir olayın sonuçlarını üstlenmesi, sorum, mesuliyet (TDK, 2021) anlamlarında kullanılan sorumluluk; vatanını sevme ya da vatanı için fedakarlikta bulunma duygusu anlamına gelen vatanseverlik; Aktepe tarafindan toplumdaki bireyler arasında bağl1lı̆ğ güçlendiren, eksiklikleri gideren, boşlukları dolduran önemli bir duygu (2010) olarak tanımlanan yardımseverlik

kök değerleri esas alınarak eserlerin her birindeki değerler doküman incelemesi yöntemiyle tespit edilmiştir. Öykülerde bulunan değerler sınıflandırılmış ve sıklık durumları belirlenmiştir. Yazar tarafından doğrudan veya örtük olarak işlenen on kök değer tespit edilmiş, bunlardan alıntılar yapılarak bulgular bölümünde sunulmuş ve her bir eserde kaç defa kullanıldıkları tablolar halinde gösterilmiştir.

\section{Verilerin Analizi}

Araştırmada, Samed Behrengi'nin "Sevgi Masalı", "Bir Şeftali Bin Şeftali” ve "Kel Güvercinci” öyküleri on kök değerin kullanım sıklığı açısından betimsel analize tabi tutulmuştur. Toplanan verileri açıklayabilecek kavramlara ve ilişkilere ulaşmak için yapılan betimsel analizinin temel amacı, elde edilen verileri 
önceden belirlennmiş temalar ışığında özetlemek ve yorumlamaktır (Yıldırım ve Şimşek, 2018).

Çalışmada 2019 Türkçe Dersi Öğretim Programında yer alan on kök değer bakımından tüm eserler taranmıştır. 2019 Türkçe Dersi Öğretim Programında yer alan on kök değer sınıflandırması temel alınmıştır. Eserlerdeki kök değerlere örnek bölümler doğrudan alıntılarla gösterilmiştir. Eserlerin farklı bölümlerinde tekrarı olsa bile tespit edilen değer ifadeleri bulgulara eklenmiştir. Bulguların yer aldığı eserlerin ismi kısaltılarak sayfa numarasıyla beraber gösterilmiştir. Verilerin analizi yapılırken araştırmanın amacı ve soruları dikkate alınmıştır. Araştırmacılar tarafından yapılan analiz işlemlerinden sonra 1'i doçent, 1 'i doktor öğretim üyesi olan uzmanların incelemesine ve görüşlerine başvurulmuştur. Böylece kodlara karşı1ık gelen değerler arasındaki uyum husussunda tavsiyeleri alınmış ve gerekli düzenlemeler yapılmıştır.

\section{Çalışmanın Geçerliliği ve Güvenirliliği için Yapılan İşlemler}

$\mathrm{Bu}$ araştırma sürecinde geçerlilik ve güvenirliğin sağlanması için aşağıda sıralanan çalışmalar yapılmıştır:

- Çalışmaya başlamadan önce bir planlanma yapılmış ve işlem basamakları belirlenmiştir.

- Verilerin toplanmasından analiz edilip sonuçlara ulaşılmasına kadar olan bütün aşamalar birbiriyle bağlantılı ve tutarlı bir şekilde sürdürülmüştür.

- Araştırmanın yöntemi, süreci ve sonuçlarına yönelik çalışmalar açık ve ayrıntılı bir biçimde açıklanmıştır.

- Çalışmanın inanılırlığını sağlamak için uzman incelemesine ve görüşlerine başvurulmuştur.

- Çalışmanın iç geçerliliğini sağlamak için, çalışmanın biçimlendirilmesi hakkında alan uzmanı bir meslektaştan (peer examination) görüş alınmıştır.

- Diş geçerlilik için ise zengin betimleme (rich, thick description), durumun tipik özelliklerini anlatma (typicality or modal category) teknikleri kullanılmıştır.

- Güvenirlik için araştırmacılar çalışmayı belirli bir sistem içinde aşama aşama geliştirmiş ve her bir basamağı detaylı bir şekilde anlatmıştır.

- Araştırmacılar tarafından yapılan baştan sona kadar gerçekleştirdiği bütün 
işlemlerde araştırma etkinliklerinde tutarlı davranıp davranılmadığını belirlemek üzere 1'i doçent, 1'i doktor öğretim üyesi olmak üzere 2 akademisyen "tutarlık incelemesi" yapmıştır.

- Derinlemesine araştırma ve inceleme anlayışı (verilerin toplanması, analiz edilmesi ve değerlendirilmesi) benimsenmiştir.

- Çalışmanın aktarılabilirliği için, araştırma süreci okuyucuya ayrıntılı bir şekilde açıklanmaya çalışılmıştır.

- İşlenmemiş veriler, bulgular, yorum ve öneriler kayıt altına alınarak doğrulanabilirlik ölçütünün sağlanması amaçlanmıştır.

\section{Bulgular}

Araştırmanın bu bölümünde; Samed Behrengi'nin "Bir Şeftali Bin Şeftali", "Sevgi Masalı" ve "Kel Güvercinci" adlı eserlerinde yer alan kök değer unsurları tablo ve alıntılarla ele alınacaktır.

Samed Behrengi'nin “Sevgi Masalı" adlı öyküsünde, 2019 Türkçe Dersi Öğretim Programı'nda yer alan kök değerlere ait bulgular

"Sevgi Masalı" eserinde yer aldığı belirlenen değerlerin kullanım sıklığı 1.Tablo'da gösterilmiştir. Tespit edilen değerler kendi başlıkları altında örnekler verilerek yorumlanmıştır.

Tablo 1: Sevgi Masalı Kitabında Yer Alan Değerler

\begin{tabular}{lll}
\hline Değerlerin Adı & $\mathrm{f}$ & $\%$ \\
\hline Adalet & 4 & 9,3 \\
\hline Sevgi & 24 & 55,8 \\
\hline Sabır & 3 & 6,9 \\
\hline Sorumluluk & 6 & 13,9 \\
\hline Dürüstlük & 5 & 11,6 \\
\hline Dostluk & - & - \\
\hline Saygı & 1 & 2,3 \\
\hline Yardımseverlik & - & - \\
\hline Öz Denetim & - & - \\
\hline Vatanseverlik & - & - \\
\hline
\end{tabular}




\section{Adalet değeri}

Zamanın birinde bir bey vardı. Halk, yoksulluk içinde çırpınırken, beyin sarayında yok yoktu (Sevgi Masal1, s. 1).

$\mathrm{Bu}$ bölümde yazar doğrudan adalet vurgusu yapmasa da adil olmayan bir durumdan bahsetmiştir. Halktan sorumlu olan beyin halkından farklı olarak varlık içinde yaşaması, yazar tarafından adaletli bir durum olarak görülmemiştir.

O günden sonra, ister bilerek olsun, isterse bilmeden başlarını kaldıranları kamçılatıyordu. Bu karara karşı gelenler de yırtıcı hayvanlara yem ediliyordu (SM, s. 9).

$\mathrm{Bu}$ bölümde yazar çocuklara adaletin yokluğunda yaşanabilecekleri sezdirmeye çalışmıştır. Böylesi durumların yaşanmaması için güçlü bir adalet anlayışının toplum tarafından benimsenmesi gerekir. Aksi halde adaletin yokluğu zalimleri daha da zalim yapar.

\section{Sevgi değeri}

Kız Hanım'ın içi sevgiyle dolmuştu. Gözlerinde biriken yaşı akıttı ve:

-Koç Ali, dedi. Ben, bir bey kızı olduğumu unuttum artık. Şimdi de birlikte, geçenleri unutalım. Yalnız seninle olmak istiyorum. Senin sevgin olmadan yaşayamam. Al götür beni. Senin yanında, halk nasıl yaşıyorsa öyle yaşamak istiyorum (SM, s. 62).

Bu paragrafta Kız Hanım içindeki sevgiyi Koç Ali’ye samimi bir şekilde dile getirmiştir. İçten bir şekilde dile getirilen bu sözler, saf sevgi içermekte ve sevenin sevdiğine olan sevgisinin yaşamak kadar değerli olduğunu anlatmaktadır.

Koç Ali, bütün bunları görevi olduğu için yapmıyordu, içinden geliyordu, istiyordu. Çünkü gönlünü bağlamıştı bey kızına. Sevdalıydı. Onulmaz bir sevdaydı bu, ama ne yapsin ki seviyordu onu (SM, s. 32).

Bu bölümde Koç Ali, görevi olmasa da sevdiği için bazı sıkıntılara katlanmıştır. Bu ifadeler ile seven sevdiği için her şeyi yapar düşüncesi sezdirilmeye çalışılmıştır.

\section{Sabır değeri}

-Hoş geldiniz amca oğulları, dediler. Sonra bana bakıp:

-Sen de hoş geldin küçük amca oğlu, dediler. Küçük kız kardeşimiz Lale, senin sabırlı olmanı diledi. Biliyorsun kış çok uzun ve sert geçti. Bir tek lale soğanı 
bırakmadı kurutmadık. Eğer kız kardeşimiz Lale, özveride bulunup da orda kalmasaydı, bu yıl dağlarda hiçbir lale çiçek açmayacak, bu güzelim topraklarda bir daha lale bitmeyecek, halk da bir daha lale göremeyecekti. Kaldı ki sizler de hiçbir zaman bizim yerimizi öğrenemeyecektiniz. Çünkü yerimizi soracağınız bir lale olmayacaktı (SM, s. 47).

Yapılan bu alıntıda yazar, neden sabırlı olunması gerektiğini anlatarak okuyucunun çıkarım yapabilmesini sağlamıştır. Çünkü sabır olmayan bir ruhta kişi kendini kaybedip yanlış şeyler yapabilir.

Mektubu okuyunca öyle bir duygulandık ki sorma. Hemen o gece yola çıkmak istedik. Ama daha kışın ortasındaydık. İlkbaharın kızıl lalesinin açmasına zaman vardı. Biz de ne Berhut Çölü’nü biliyorduk ne de ormanın yerini (SM, s. 44).

Bu bölümde yazar, sabır etmenin bazen zaruri olduğunu ve beklemenin her şeyden daha akıllıca olduğunu anlatmaya çalışmıştır. "Sabır önceleri zehirdir, huy edinirsen bal olur." diyen Mevlana, istenilen sonuçların alınabilmesi için beklemek gerektiğini anlatmaya çalışmıştır. Yazar da bu bölümde bunu sezdirmeye çalışmıştır.

\section{Sorumluluk değeri}

Koç Ali çelik çomağını alır, sarayın binlerce oyuncağın bulunduğu özel bölümüne konulması için oyuncak sorumlusuna verirdi. Bunun arkasından, bey kızının çelik çomak oynarken giydiği kıyafetleri, yine özel odaya koymasını, sonra da yemekte giyeceği giysilerden birini çıkarmasını giyim kuşam sorumlusundan isterdi. Daha sonra mutfağa gider, özel aşçıya, çelik çomaktan sonra yenecek yemeği hazırlamasını söylerdi. Çünkü her oyundan sonra, daha önceden hazırlanmış programa göre özel yemekler hazırlanırdı. Bey kızı uyuduğu zaman bile o, kapının önünde kıvrılır, bir süre kestirirdi. Koç Ali’nin günlük görevleriydi bunlar (SM, s. 6).

$\mathrm{Bu}$ paragrafta yazar, her işten bir kişinin sorumlu olduğunu ve kendilerine verilen görevleri yerine getirmeleri gerektiğini belirtmiştir. Bu sayede sorumluluğun bazen verilen vazifeyi yerine getirmek olduğu sezdirilmeye çalışılmıştır.

Savaşçılarımıza, kış bitmeden bin tane, çifte su verilmiş kılıçlar yetiştirecektik. Onun için işimizin başına döndük. Ve de kış bitmeden kılıçları teslim ettik (SM, s. 44-45).

Bu bölümde kahramanların işlerini tamamlamaları gerektiğini anlatmaları ve zamanında teslim etmeleri sorumluluk bilinciyle yapılan davranışlardır. Sorumluluk bazen istemesek de bize vazife olunan işleri tamamlayabilmektir. 


\section{Dürüstlük değeri}

Bir uşak, bir bey kızına nasıl sevdalanabilirmiş. Ben bir bey kızıyım, sen de benim uşağımsın. Bu ne biçim bir söz? Yıkıl karşımdan! Seni bir daha yüzüm görmesin. Git, uşakları çağır, tahtırevanımı hazırlayıp beni alsınlar. Seni de kovsular ki, kem gözlerin üzerimde olmasın.

Koç Ali, gidip uşaklara haber verdi. Tahtırevanla geldiklerinde bey kızını baygın buldular. Koç Ali’nin yakasına yapıştılar:

-Ne yaptin ona?

-Bir şey yapmadım. Öfkelenip bana vurdu. Sonra da bayılmış olmalı. Yemin ederim ki aynen böyle oldu.

Koç Ali'ye kimse inanmadı (SM, s. 7-8).

Bu bölümde yazar, her şeye rağmen Koç Ali’yi dürüst davrandırıp ona doğruları söyletmiştir. Sonuçları bile bile doğruları söylemek büyük bir erdem olan dürüstlüğe örnektir.

-Bey kızısın, ama yapayalnızsın. Bir tek arkadaşın bile yok. Sana güzel olduğunu söyleyecek bir kimse bile yok (SM, s. 16).

$\mathrm{Bu}$ bölümde adalet anlayışından yoksun bir bey kızına korkmadan doğruları söyleyen Koç Ali, güzel bir dürüstlük örneği göstermiştir. Dürüstlük korkakların işi değildir. Çünkü sonunun ne olacağını düşünen bireyler menfaatleri doğrultusunda dürüst davranmayıp yalan söyleyebilir. Bu nedenle yazar, korkmadan doğruları söylemenin faziletini okuyucuya sezdirmeye çalışmıştır.

\section{Saygı değeri}

- Koç Ali, sana bir şeyler söylemek istiyorum. Ama gücenir, kızarsın diye çekiniyorum.

Koç Ali güldü:

-Anladım, dedi. Duygularım beni yanıltmaz. Sen bacımı eş olarak istiyorsun değil mi?

- Evet.

Koç Ali yine güldü:

-Benden yana çekinme. Ama karar kendisinindir. Kalk, şimdi gidelim. O da "Olur" derse ben de sevinirim. Sürüyü bundan sonra da tek başıma otlatırım (SM, s. 51-52). 
$\mathrm{Bu}$ bölümde kardeşini de bir birey olarak gören Koç Ali, onun adına karar veremeyeceğini belirterek kız kardeşinin fikrine saygı duymakta ve onun vereceği kararı önemsemektedir. Bu sayede başkası adına karar vermenin, kardeş de olsa, doğru bir davranış olmadığı sezdirilmeye çalışılmıştır.

Samed Behrengi'nin "Bir Şeftali Bin Şeftali" adlı öyküsünde, 2019 Türkçe Dersi Öğretim Programı'nda yer alan kök değerlere ait bulgular

"Bir Şeftali Bin Şeftali" eserinde yer aldığı belirlenen değerlerin kullanım sıklığı 2.Tablo'da gösterilmiştir. Tespit edilen değerler kendi başlıkları altında örnekler verilerek yorumlanmıştır.

Tablo 2: Bir Şeftali Bin Şeftali Kitabında Yer Alan Değerler

\begin{tabular}{lll}
\hline Değerlerin Adı & $\mathrm{f}$ & $\%$ \\
\hline Adalet & 5 & 16,6 \\
\hline Sevgi & 5 & 16,6 \\
\hline Sabır & 11 & 36,6 \\
\hline Sorumluluk & 2 & 6,6 \\
\hline Dürüstlük & 1 & 3,3 \\
\hline Dostluk & 3 & 10 \\
\hline Saygı & - & - \\
\hline Yardımseverlik & 3 & 10 \\
\hline Öz Denetim & - & - \\
\hline Vatanseverlik & - & - \\
\hline
\end{tabular}

\section{Adalet değeri}

Birkaç yıl önce köyün zengini kurak ve susuz toprakları parça parça yapıp köylülere satmış; bu verimli bahçeyi de kendi alıkoymuştu (Bir Şeftali Bin Şeftali, s. 3).

$\mathrm{Bu}$ paragrafta, yazar bir adaletsizlik olduğunu doğrudan söylemese de adil olunmadığı konusunda bir mesaj vermektedir. Köyün zengininin verimli bahçeleri alıkoyması adaletsizliğe işarettir ve bu durum sezdirilmeye çalışılmıştır.

\section{Sahip Ali:}

-Sanki biz insan değiliz! Bütün meyveleri topluyor, sonra da zıkkımlansın diye o ite götürüyor. Başkasının canı yokmuş gibi. Ama suç onlarda değil. Bütün suç 
bizde. Elimizi, kolumuzu bağlamışız. Herifçioğlunun köyü soyup soğana çevirmesine göz yumuyoruz (BŞBŞ, s. 17-18).

Bu bölümde yazar Sahip Ali’ye, adaletsizliğe içten içe sitem ettirmektedir. Adaletsizliğin en büyük sebeplerinden birinin de susmak olduğu unutulmamal1dır. Haksızlık karşısında susmak haksızlığa ortak olmaktır. Bu durum bu paragrafta güzel bir şekilde sezdirilmeye çalışılmıştır.

\section{Sevgi değeri}

Güzel kızım bana sıkıca sarılıyor, öz suyumu emiyordu. Canımı da acıtıyordu, ama ona hiç kızmıyordum. Analık duygularımla onu hoş görüyordum. O, benim güzeller güzeli biricik kızımdı (BŞBŞ, s. 53).

Bu bölümde yazar, anne sevgisini dolaylı bir şekilde ifade etmeye çalışmıştır. Alıntıda sevgi ifadesi bulunmasa da bir annenin yavrusuna oluşabilecek kızgınlığını ancak annenin yavrusuna olan sevgisinin engelleyebileceği sezdirilmeye çalışılmaktadır.

Polat, konuşmasını bitirince yeniden ağlamaya başladı. Onlara, ne kadar büyük ve içten bir sevgi ile bağlı olduğumu, onları ne kadar çok sevdiğimi o an daha iyi anladım. Sahip Ali’yi bir daha göremeyeceğimi düşündükçe çok üzüldüm. $\mathrm{Bu}$ üzüntüyle tüm yapraklarımı dökmek, köküme kadar kuruyup bir daha hiç filizlenmemek istedim (BŞBŞ, s. 59).

Bu bölümde dostu Sahip Ali'nin öldüğünü duyan ve bu duruma çok üzülen şeftali ağacı, sevginin en saf halini cümleleriyle anlatmıştır. Çünkü canlılar sevdikleri kadar üzülürler ve şeftali ağacı da yok olma isteğiyle sevgisinin büyüklügünü anlatmaya çalışmıştır.

\section{Sabır değeri}

-Dur bakalım, acele etme. Hele gidip karnımızı bir doyuralım, ikindiye doğru gelir, alırım seni evden. Tepeye çıkıp otururuz, konuşuruz. Orada anlatırım sana neler düşündüğ̈̈mü (BŞBSS, s. 29).

Bu bölümde yazar, doğrudan belirtmese de, acele etmemesi gerektiğini söyleyerek aslında sabırlı olunması gerektiğini anlatmaya çalışmıştır. Bazen acele alınan kararların kötü sonuçlara sebep olabileceği sezdirilmeye çalışılmıştır.

Ama kararlıydım. Ne olursa olsun, her güçlüğe katlanmalı, şeftalimi korumalı ve onu olgunlaştırmalıydım. Eğer gelecekte bin şeftali verecek bir ağaç olacaksam, bu ilk sınavı kazanmalıydım (BŞBŞ, s. 51). 
Bu bölümde, sabır için önemli adımlar olan sıkıntılara göğüs germek ve karar1 olmak ifadeleri vurgulanarak sabır değerinin önemi sezdirilmeye çalışılııştır.

\section{Sorumluluk değeri}

Bahçıvanın anlattığına göre yabancı bir tarım uzmanı, kendi ülkesinden getirdiği aşıdan yapmıştı bu ağaca. Hizmetliler de bu ağaca gözleri gibi bakarlardı (BŞBŞ, s. 4).

Bu bölümde hizmetlilere kendilerine emanet edilen özel bir ağacın sorumluluğu verilmiştir. Kendilerine verilen sorumluluk gereği ağacı korumak ve ona iyi bakmak zorunda olan hizmetliler, ağaca gözleri gibi bakmışlardır. Gözü gibi bakmak deyimiyle sorumluluk duygusu sezdirilmeye çalışılmıştır.

-Haydi uyan artık! Bırak nazlanmayı, dedi. Sen yeni bir yaşamın tohumunu taşıyorsun. Haydi iş başına. Kocaman bir ağaç olup meyve vermeye can atan sen değil miydin (BŞBŞ, s. 38)?

Bazen sorumluluk başkası tarafindan verilmez. Kendiliğinden oluşan bazı sorumluluklar vardır. Örneğin bir anne başkası yap demese bile çocuklarına bakma sorumluluğuna sahiptir. Bu bölümde yaşamın tohumunu taşıyan şeftali çekirdeği, kendiliğinden oluşan bir sorumluluğa sahiptir.

\section{Dürüstlük değeri}

Sahip Ali:

-Polat, çevir başını öte yana, diye seslendi.

- Niye? Yoksa şalvarını $\mathrm{m}$ çıkaracaksın, diye güldü.

-Evet! Şalvarım ıslanırsa babam suda yüzdüğümü anlar, döver beni, dedi.

Polat:

-Daha öğleye çok be, dedi. O zamana kadar kurur.

-Zamanı mı kaldı? Baksana güneş tepemize indi (BŞBŞ, s. 28-29).

Bu bölümde Sahip Ali, yaptıklarının nedenini dürüstçe anlatmıştır. Yaptıklarımız başkalarının gözünde bizi küçük düşürse bile dürüst olmaktan, doğruyu söylemekten çekinmemeliyiz. Çünkü yalan söylendikçe devamı gelen kötü bir davranıştır.

\section{Dostluk değeri}

Ah benim güzel ağacım! Benim nazlı şeftalim! Bir bilsen ne oldu? Ama nereden bileceksin? Sahip Ali öldü. Öldü Sahip Ali’m. Yoksa yanına hiç yalnız gelir miyim? Yılan soktu sahip Alimi, yılan. Bildin mi (BŞBŞ, s. 54)? 
Bu bölümde yazar, ölen bir dostun bıraktığı derin üzüntüyü işlemiştir. Doğrudan belirtmese de dostu için üzülen Polat, aslında aralarındaki derin bağı dolaylı bir şekilde anlatmıştır.

-A güzel kızım, derdi. Sakın, güneş yakıyor diye onlara yüz çevirme. Güneş bizim dostumuzdur. Bizim besinimizi toprak verir, ama onu pişiren güneştir. Senin bu güzelliğin, diriliğin de güneştendir (BŞBŞ, s. 12).

Bu bölümde dostluğun farklı bir boyutu ele alınmıştır. "Dost acı söyler." atasözünün yazıya dökülmüş halidir yaşananlar. Dost bazen acı söylese de dostunun iyiliğini düşündüğü içindir. Bu bölümde de dost olan güneş, bazen yaksa da amacı yakmak değil pişirmek yani fayda sağlamaktır.

\section{Yardımseverlik değeri}

Koca bir kış boyunca, tatlı uykumun arasında kim bilir ne kadar düş görmüşümdür. Ama hiçbirini hatırlamıyorum desem yalan olmaz. Yalnızca bir tanesi aklımda kalmış:

Büyümüş, kocaman bir ağaç olmuşum. Polat ile Sahip Ali üzerime tırmanmış, dallarımı salıyorlar. Köyün ne kadar yoksul çocuğu varsa dibime toplanmışlar. Düşen meyvelerimi kapışıyor, ağızlarını şapırdata şapırdata yiyorlar. Ağızlarından akan meyvelerimin suları çenelerinden çıplak göğüslerine akıyor (BŞBŞ, s. 36).

Bu bölümde öykü kahramanlarının köyün yoksul çocuklarına yardımda bulunması ve yoksul çocukları sevindirmesi bir yardımseverlik örneğidir. Bu davranış ile zor durumda olanlara yardım etmenin yardımseverlik olduğu sezdirilmeye çalışılmıştır.

Boncuk Nine, bütün gece başında bekledi. Ama elinden ne gelirdi ki... İstediği bütün otları, Sahip Ali'nin babasıyla birlikte dağlardan, taşlardan toplayıp getirdik (BŞBŞ, s. 55).

Yardımseverlik zor zamanlarda ihtiyacı olana destek olmaktır. Bu bölümde Polat, Sahip Ali'nin babasıyla yardımlaşarak dağlardan taşlardan Boncuk Nine'nin istediği otları toplamıştır. Polat, dostu için elinden geleni yapmış ve dostunun babasına yardım etmiştir.

\section{Samed Behrengi'nin "Kel Güvercinci" adlı öyküsünde, 2019 Türk- çe Dersi Öğretim Programı'nda yer alan kök değerlere ait bulgular}

"Kel Güvercinci" eserinde yer aldığı belirlenen değerlerin kullanım sıklığ 3.Tablo'da gösterilmiştir. Tespit edilen değerler kendi başlıkları altında örnekler verilerek yorumlanmıştır. 


\begin{tabular}{llc}
\hline Tablo 3: Kel Güvercinci Kitabında Yer Alan Değerler & & \\
\hline Değerlerin Adı & $\boldsymbol{f}$ & $\%$ \\
\hline Adalet & 2 & 6,9 \\
\hline Sevgi & 17 & 58,8 \\
\hline Sabır & 1 & 3,4 \\
\hline Sorumluluk & 2 & 6,9 \\
\hline Dürüstlük & 2 & 6,9 \\
\hline Dostluk & - & - \\
\hline Saygı & 1 & 3,4 \\
\hline Yardımseverlik & 3 & 10,3 \\
\hline Öz Denetim & 1 & 3,4 \\
\hline Vatanseverlik & - & - \\
\hline
\end{tabular}

\section{Adalet değeri}

-Eğer haram mala el uzatmayacağına yemin edersen veririm. Yoksa sana bu külahı giydirmem.

Keloğlan:

-Tamam ana, haram mala el uzatmayacağıma yemin ediyorum, demiş (Kel Güvercinci, s. 18).

Bu bölümde Keloğlan, kendisine ait olmayan bir şeye dokunmayacağını yani adalet gereği yapması gereken şeyi dile getirmiştir. Adalet ifadesi geçmediği halde adalet değeri bu doğru yaklaşımla sezdirilmeye çalışılmıştır.

Soru ve cevaplardan elde edilen sonuçlara göre: İşçiler çalışıyor, ama ürettikleri mallardan kazanılan para Hacı'nın cebine akıyor. Üstelik işçilere de haklarını tam olarak vermiyor. Azıcık ücretle onları oyalıyor. Öyleyse Hacı'nın malı bana haram değildir (KG, s. 19).

Bu bölümde yazar öykünün kahramanına adaleti sorgulatıp kendi doğrusunu bulmasını sağlamaktadır. İnsanların haklarını alamamasının hiç de adil olmadığ1 okuyucuya sezdirilmeye çalışılmıştır.

\section{Sevgi değeri}

-Sevgilim, demiş. Seni nasıl sevdiğimi görmüyor musun? Al, götür beni buralardan. Yoksa beni zorla vezirin oğluna verecekler (KG, s. 46).

Bu bölümde padişahın kızı Keloğlan’a sevgisini açık bir şekilde dile getirmiş ve sevmediği biriyle değil sevdiği biriyle olmak istediğini anlatmıştır. Bu sayede sevginin birliktelik için önemli bir duygu olduğu sezdirilmeye çalışılmıştır. 
Onu öyle çok seviyorum ki bir bilse, diyormuş. Bir bilse ne çok sevdiğimi, bir an bile bekletmezdi beni. Ya nöbetçilere yakalanır da öldürülürse diye yüreğim küt küt ediyor (KG, s. 44).

$\mathrm{Bu}$ bölümde sevdiği için meraklanan ve ona bir şeyler olur kaygısı taşıyan padişahın kızı, bu duyguları sevdiğinden yaşamaktadır.

\section{Sabır değeri}

-Hadi, kaçır beni şimdi.

-Yoo! Şimdi olmaz. Birkaç gün bekle. Ben sana, ne zaman kaçacă̆ımızı bildiririm (KG, s. 47).

Bu bölümde doğrudan sabır ifadesi geçmese de uygun zamanın gelmesini beklemenin sabır gerektirdiği sezdirilmiştir. Sabır kendimizi kontrol etmeyi ve uygun zamanı beklemeyi gerektir. Aksi halde yanlış sonuçlara katlanmamız gerekebilir.

\section{Sorumluluk değeri}

Keloğlan, her sabah horoz sesiyle, gün ağarırken uyanır, yollara düşermiş. Çayırlarda, bayırlarda dolaşır, çalı çırpı, ot diken ne bulursa toplar, sırtına yüklenip eve getirirmiş. Kara keçisi Keloğlan’1 görünce sevinçle zıplar, getirdikleriyle karnını bir güzel doyururmuş. Arta kalanları da kışın yesin diye ayırır, bir kısmını da satmak için dama çıkarıp orada saklarmış (KG, s. 4).

Bu bölümde yazar, doğrudan belirtmese de evin tek erkeği olarak Keloğlan'ın üstlendiği sorumluluğu sezdirmeye çalışmıştır. Bazen şartlar bize sorumluluk almayı zorunlu hale getirebilir.

-Beni bağışlayın sultanım, demiş. Ben bir emir kuluyum. Babanızın kölesiyim. Her yeri aramamızı padişahımız buyurdu. Onun buyruğunu yerine getirmek boynumuzun borcu. Benim bir suçum yok (KG, s. 49-50).

$\mathrm{Bu}$ bölümde, padişah kızının odasını aramaya gelen vezirin oğlu, yapmış olduğu aramayı kendisine verilen sorumluluk gereği yaptığını belirtmiştir. Sorumluluk gereği yapılması gerekenler, adalet kuralları çerçevesinde olmak koşuluyla, bazılarını rahatsız etse bile yerine getirilmesi doğrudur.

\section{Dürüstlük değeri}

Padişah oturup kızıyla konuşmak istemiş. Kimileri, "Kız, derdini hiç kimseye açmaz." demişler. Bu ya korkudan ya da gelenek görenektenmiş.

Ama kız, hiçbir şey saklamayıp derdini babasına olduğu gibi anlatmış. 
Padişah; kızının, karşıdaki kulübede yaşayan kel güvercinciye sevdalandığını duyunca yere yurda sığmamış. Ağzı yüzü köpükler içinde kalmış. Ellerini yukarılara kaldıra kaldıra bağırmış, kızını azarlamış (KG, s. 9).

Sonuçları ne olursa olsun kişilerin sorunlarını dürüstçe anlatabilmesi önemlidir. Çünkü bazen korku gibi nedenler insanları yalan konuşmaya itebilir. $\mathrm{Bu}$ nedenle sonuçları ne olursa olsun çocuklara dürüst davranma cesareti verilmelidir. Bu bölümde padişahın kızı babasından hiçbir şey saklamadan olan biteni anlatma cesareti göstermiş ve dürüst davranmıştır.

-İyi ama anamla ben karnımızı zor doyuruyoruz. Sana nasıl bakarım, ne ile geçindiririm seni. Üstelik sen bir padişah kızısın. Elinden hiçbir iş gelmez ki (KG, s. 46).

Bu bölümde Keloğlan, padişahın kızına dürüstçe durumunu ifade etmiştir. Yalan söyleyerek sevdiğini mutlu edecek sözler söyleyebilirdi ancak doğru olanı yaparak dürüst davranmıştır. Bir an için mutlu etmeyi düşündüğümüz insanlar, bize dürüst davrandığımız için daha çok değer vereceklerdir.

\section{Saygı değeri}

\section{Keloğlan:}

-Buyruğunuz karşısında boynum kıldan incedir padişahım, demiş. Yalnız, ellerimi çözsünler ki huzurunuzda el pençe divan durayım; külahımı versinler ki, çıplak başımı örteyim. Böyle eli bağlı, başı açık karşınızda saygısızlık etmiş olmak istemiyorum (KG, s. 52).

Bu bölümde Keloğlan, padişahın makamına ve şahsına saygısını dile getirmiştir. Bazen kişiler kötü olabilir ama kişilerin temsil ettiği topluluk saygıyı hak eder. Saygı değeri bu örnekteki gibi farklı bir boyutla sezdirilmeye çalışılmıştır.

\section{Yardımseverlik değeri}

Aldığı paradan çok azını kendine ayırmış. Sonra, yol üzerindeki yoksul evlerin kapısını çalmaya başlamış. Kapıyı açanlara bir solukta:

-Al şu altınları, birkaç tümeni... Çocuklarına harca, sıkıntılarından kurtul. Kimseye de bir şey söyleme, diyormuş.

Kapıyı açanlar, karşılarında kimseyi görmüyorlarmış. Sadece bir ses duyuyorlar, sonra da birdenbire ayaklarının dibindeki altınlara paralara bakıp şaşırıyorlarmış. Keloğlan'ı bir türlü fark edemiyorlarmış. Keloğlan, böylece birçok yoksula para verip onların yüzünü güldürmüş. Onların sevinçleri karşısında da büyük mutluluk duyuyormuş (KG, s. 27). 
Maddi ve manevi anlamda sıkıntılar yaşayan insanlara yardımda bulunmak, onların sıkıntılarını gidermek, dertlerine ortak olmak yardımseverliğin gerekleridir. Bu değer çocuklara sadece yaparak ve yaşayarak öğretilebilir. Bu bölümde Keloğlan'ın yardıma muhtaç insanlara yardımlarda bulunarak onları mutlu etmesi güzel bir yardımseverlik örneğidir.

\section{Öz denetim değeri}

-Söyle bakalım Keloğlan. Şu Hacı Ali denen adamın malı sana haram mı, helal mi? -Bu kadar parayı nereden bulduğuna bağlı? Eğer parasını helalinden kazandıysa bu mal bana haramdır. Ama haram yoldan kazandıysa bana helaldir. Adam faizcilik yapıyormuş. Ama fabrikaları da varmış.

-Peki, bu fabrikalarda kimler çalışır?

-Fakir işçiler çalışıyor.

-Pekâlâ, işçilerin hakkını tam ödüyor mu?

-Ne gezer? Herkes şikâyetçi zaten.

-Hoca Ali ne yapar?

-Yan gelip yatar, keyfine bakar. Parmağını bile kıpırdatmadığı halde bütün kazancinı toplar.

Soru:

-Iş̧̧̧iler çalışmaz ise fabrikanın durumu ne olur?

Cevap:

-Tümü de kapanır.

Soru:

-O durumda Hacı, gene çok para kazanabilir mi?

Cevap:

-Elbette kazanamaz.

Soru ve cevaplardan elde edilen sonuçlara göre: İşçiler çalışıyor, ama ürettikleri mallardan kazanılan para Hacı'nın cebine akıyor. Üstelik işçilere de haklarını tam olarak vermiyor. Azıcık ücretle onları oyalıyor. Öyleyse Hacı'nın malı bana haram değildir (KG, s. 19-21).

Bu bölümde, Keloğlan'ın iç konuşma yaparak doğru ve yanlış olanı ayırt etmesi ve bir sonuca varması bir öz denetim örneğidir.

Samed Behrengi'nin incelediğimiz üç eserinde kullanılan değerlerin toplam kullanım sıklığı Tablo 4’te gösterilmiştir. 
Tablo 4: Eserlerde Yer Alan 10 Kök Değerin Kullanım Sıklığı ve Yüzdeliği

\begin{tabular}{llc}
\hline Değerlerin Adı & $\boldsymbol{f}$ & \% \\
\hline Adalet & 11 & 10,7 \\
\hline Sevgi & 46 & 45 \\
\hline Sabır & 15 & 14,7 \\
\hline Sorumluluk & 10 & 9,8 \\
\hline Dürüstlük & 8 & 7,8 \\
\hline Dostluk & 3 & 2,9 \\
\hline Saygı & 2 & 1,9 \\
\hline Yardımseverlik & 6 & 5,8 \\
\hline Öz Denetim & 1 & 0,9 \\
\hline Vatanseverlik & - & - \\
\hline Toplam & $\mathbf{1 0 2}$ & $\mathbf{1 0 0}$ \\
\hline
\end{tabular}

Samed Behrengi'nin incelenen öykülerinde en çok sevgi değerinin kullanıldığg görülmüştür. Sevginin aşk boyutuyla ele alındığı Sevgi Masalı adlı eserde, değerleri bazen doğrudan aktarmak yerine dolaylı yollarla sezdirmeye çalışan, anlama işini öğrenciye bırakan Samed Behrengi, sevgi değerini 24 kez kullanmıştır. Sevginin aşk boyutuyla ele alındığı bir diğer eser olan Kel Güvercinci adlı eserde hayvan sevgisine de sık sık değinilmiş ve toplamda sevgi değeri 17 kez kullanılmıştır. Daha çok doğa sevgisinin anlatıldığı Bir Şeftali Bin Şeftali adlı eserde 5 kez sevgi değeri kullanılmıştır. Sevgi değerinden sonra en çok kullanılan değer sabır değeridir. Özellikle Bir Şeftali Bin Şeftali adlı eserde kullanılan sabır değeri, doğadan verilen örneklerle sezdirilmeye çalışılmıştır. Adalet değerini doğrudan kullanmak yerine adaletsizlik üzerinden yaşananalarla dolaylı bir şekilde ele alan Samed Behrengi, bu değeri eserlerinde toplamda 11 kez kullanmıştır. İncelenen eserlerde sevgi, sabır ve adalet değerlerinden sonra sırasıyla en çok kullanılan değerlerin sorumluluk, dürüstlük, yardımseverlik, dostluk, sayg1, öz denetim değerleri olduğu tespit edilmiştir. Okuyuculara daha çok insan, hayvan ve doğa sevgilerinin sezdirilmeye çalışıldığı eserlerde dikkat çekici bir şekilde vatanseverlik değerine üç eserde de rastlanmamıştır.

\section{Sonuç, Tartışma ve Öneriler}

Çocukların hayatına yön veren, onları toplumla bütünleştiren değerlerin eğitiminde yazılı, sözlü veya görsel birçok materyal kullanılmaktadır. Değerler eğitiminde kullanılan yazılı materyallerin başında ise edebi eserler gelmektedir. Çocuklara aktarılmak istenen duygu, düşünce, toplumsal değer ve davranış 
şekilleri, edebi eserler aracılığıyla daha etkili ve kalıcı olarak verilebilir (Erdal, 2009). İçinde sayısız bilgi ve değer-takdir duygusunu barındıran edebi eserler aracılığ ile değerleri aktarmak mümkündür. Bu bağlamdan hareketle bu çalışmada, 2019 Türkçe Dersi Öğretim Programında yer alan kök değerler dikkate alınarak Samed Behrengi'nin "Sevgi Masalı", "Bir Şeftali Bin Şeftali” ve "Kel Güvercinci” adlı eserleri incelenmiştir.

Eserlerde bazı değerler, bütün hikâyelerde ele alınırken bazı değerlerin tek bir hikâyede ağırlıklı olarak ele alındığı görülmüştür. Örneğin "Sevgi Masalı" adlı eserde daha çok sevgi, dürüstlük ve sorumluluk; "Bir Şeftali Bin Şeftali" adlı eserde sabır, adalet; "Kel Güvercinci" adlı eserde ise sevgi ve yardımseverlik gibi değerlere daha çok yer verilmiştir. Hayatın gerçeklerini, hayal ürünü olaylar içinde dolaylı yoldan nakleden Samet Behrengi (Erkan ve Aykaç, 2014), eserlerinde bazı mesajları örtük bir şekilde vermiştir. Örneğin: ““'Güzel kızım bana sıkıca sarlliyor, öz suyumu emiyordu. Canımı da acıtıyordu, ama ona hiç kızmıyordum. Analık duygularımla onu hoş görüyordum. O, benim güzeller güzeli biricik kızımdl." (BŞBŞ, s. 53) bölümünde yazar, anne sevgisini dolaylı bir şekilde ifade etmeye çalışmıştır. Anlatımda sevgi ifadesi bulunmasa da bir annenin yavrusuna oluşabilecek kızgınlığını ancak annenin yavrusuna olan sevgisinin engelleyebileceği sezdirilmeye çalışılmaktadır. Aynı şekilde "Zamanın birinde bir bey vardı. Halk, yoksulluk içinde çırpınırken, beyin sarayında yok yoktu." (SM, s. 1) bölümünde de yazar doğrudan adalet vurgusu yapmasa da adil olmayan bir durumdan bahsetmiştir. Ayrıca kahramanların çocuk olması ve çocuk okuyucuya rol model olacak şekilde seçilmesi, çocukların masal kahramanlarıyla özdeşim kurarak kök değerleri içselleştirmesine olanak sağlandığını söylemek mümkündür. "Büyümüş, kocaman bir ağaç olmuşum. Polat ile Sahip Ali üzerime tırmanmış, dallarımı salıyorlar. Köyün ne kadar yoksul çocuğu varsa dibime toplanmışlar. Düşen meyvelerimi kapışlyor, ağızlarını şapırdata şapırdata yiyorlar. Ağızlarından akan meyvelerimin suları çenelerinden çıplak göğüslerine aklyor...” (BŞBŞ, s. 36) örneğindeki gibi çocuk öykü kahramanlarının köyün yoksul çocuklarına yardımda bulunarak yoksul çocukları sevindirmeleri çocuk yaştaki okuyucular için bir rol model seçimi olabilir.

Değerlerin bazen doğrudan bazen de sezdirilerek verildiği eserlerin incelendiği bu çalışmaya benzeyen alanyazında birçok çalışma bulunmaktadır. Yeniay (2019), Demir (2019) ve Kumbasar (2011) tarafından yapılan çalışmalarda; değerlerin benzer bir şekilde bazı bölümlerde doğrudan, bazı bölümlerde ise sezdirilerek verildiği tespit edilmiştir. Söz konusu çalışmalar bu yönleriyle Samed Behrengi'nin eserlerinin incelendiği bu çalışma ile örtüşmektedir 
Kök değerler üzerine yapılan çalışmaların büyük çoğunluğunda ve Samed Behrengi'nin incelenen eserlerinde en sık geçen değerin sevgi (46) değeri olduğu tespit edilmiştir. Bu sonuçlar, daha önceden Samed Behrengi'nin “Küçük Kara Balık" adlı eserini inceleyen Boyacı ve ark. (2017) ile Calp ve Calp'ın (2019) çalışmaları ile örtüşmektedir.

Tozlu ve Yüce'nin (2020) Hamdi Ülker'in eserlerini kök değerler açısından inceledikleri çalışmada en çok sevgi değerine rastlanmıştır. Aynı şekilde Bulut (2021) tarafından Ayla Kutlu'nun "Merhaba Sevgi” adlı çocuk romanının değerler eğitimi ve on kök değer açısından incelendiği çalışmada sırasıyla en çok sevgi, dürüstlük, yardımseverlik, sorumluluk ve saygı değeri tespit edilmiştir. Alanyazında değerler eğitimi açısından incelenen birçok eserde sevgi değerinin en sık kullanılan değer olduğu tespit edilmiştir (Abac1, 2018; Aydoğdu ve Alkan, 2020; Baran Yir, 2019; Batur ve Yücel 2012; Binyıl Şahin, 2019; Doğaner, 2021; Eker ve Yıldırım, 2017; Ergül Özkul, 2019; Erol, 2014; Gümüş, 2017; Karagöz, 2017; Kumbasar, 2011; Kuru ve Keklik 2016; Otmar ve Erdem, 2019; Özay, 2019; Özbaşı, 2020; Senek, 2018; Topbaş, 2015; Utku, 2020; Y1lmaz, 2018). Bu yönleriyle ismi geçen çalışmalar, bu çalışma ile paralellik göstermektedir.

Adalet değerine yer verilen cümlelerde daha çok adaletsizlik, eşitsizlik vurgusu yapılmıştır. Adalet değeri adaletsizliğin ve eşitsizliğin olduğu durumlarla sezdirilmeye çalışılmıştır. Binyıl Şahin (2019)'in çalışmasında da benzer bir şekilde adalet değerinin sezdirilmeye çalışıldığı tespit edilmiştir.

Samed Behrengi'nin üç eserinde de on kök değerden biri olan vatanseverlik değerine hiç rastlanmamıştır. Karagöz'ün (2017) yaptı̆̆ çalışmada vatanseverlik değerinin en az yer verilen değerlerden biri olduğu (3 defa) belirtilmiştir. Kumbasar (2011) tarafından yapılan çalışmada da vatanseverlik değerinin yeterince ele alınmadığı belirlenmiştir. Vatanseverlik değerinin kullanım sıklığı yönüyle söz konusu çalışmlar benzerlik göstermektedir.

\section{Öneriler}

- On kök değerin aktarımına katkı sağlayabilecek pek çok hususa rastlanan bu üç eser ilkokul çağındaki çocuklar için değerler eğitiminde kullanılabilir.

• "Bir Şeftali Bin Şeftali” adlı öykünün sevgi, sabır, adalet, dostluk, yardımseverlik, sorumluluk; "Sevgi Masalı" adlı öykünün adalet, dürüstlük, sevgi, sorumluluk, sabır; "Kel Güvercinci" adlı öykünün ise sevgi, adalet, yardımseverlik, sorumluluk, dürüstlük kök değerlerinin aktarımında doğrudan ya da dolaylı bir şekilde düzenlenecek etkinliklerde kullanılabilecek faydalı 
birer eğitim materyalleri olarak tavsiye edilebilir.

- Değerler eğitimi için Samed Behrengi'nin incelenen eserleri okul kitaplarında örnek metin olarak kullanılabilir.

- Samed Behrengi'nin 3 eseri üzerine yapılan incelemenin kapsamı genişletilerek diğer eserleri de içine alan bir kök değer incelemesi yapılabilir.

\section{Kaynakça}

Abacı, E. (2018). Behiç Ak’ın çocuk kitaplarının değerler eğitimi açısından incelenmesi (Yüksek Lisans Tezi). Bülent Ecevit Üniversitesi, Sosyal Bilimler Enstitüsü, Zonguldak.

Akbaba Altun, S. (2003). Eğitim yönetimi ve değerler. Değerler Ĕ̆itimi Dergisi, $1(1), 8$.

Akbaş, O. (2004). Türk millî eğitim sisteminin duyuşsal amaçlarının (değerlerinin) ilköğretim II. kademedeki gerçekleşme derecesinin değerlendirilmesi (Yayımlanmış Doktora Tezi). Gazi Üniversitesi, Eğitim Bilimleri Enstitüsü, Ankara.

Aktepe, V. (2010). Illköğretim 4. sinıf sosyal bilgiler dersinde "yardımseverlik" değerinin etkinlik temelli ögretimi ve öğrencilerin tutumlarına etkisi (Yayınlanmamış Doktora Tezi). Gazi Üniversitesi, Ankara.

Aktepe, V. (2016). Ailede değerler eğitimi ve program ihtiyac1. Turan, R., Ulusoy, K. (Ed.). Farklı Yönleriyle Değerler Eğitimi içinde (78-94). Pegem Akademi Yayınları.

Albayrak, N. (2004). Ansiklopedik halk edebiyatı sözlüğ̈̈. Leyla ile Mecnun Yayınc1lik.

Alimcan, D. ve Altunay Şam, E. (2017). Sosyal bilgiler dersi boyutunda değerler eğitiminin önemi ve medyanın değerler üzerindeki etkisi. Millî Ĕgitim Dergisi, 46(215), 239-259.

Arseven, T. (2005). Mesaj açısından çocuk kitapları. Hece Dergisi, (104-105), 46-51.

Aslan, F. (2019). Ahmed Mürşidi Efendi'nin pendnâmesindeki değer eğitimi unsurlarının incelenmesi (Yayımlanmamış Yüksek Lisans Tezi). Ağrı İbrahim Çeçen Üniversitesi, Sosyal Bilimler Enstitüsü, Ağrı.

Aydın, M. (2011). Değerler, işlevleri ve ahlak, Eğitime Baklş, 7(19), 39-45.

Aydın, M. Z. (2010). Okulda değerler eğitimi. Eğitime Baklş, 6(18), 16-19.

Aydoğdu, H. ve Alkan, E. (2020). Değerler eğitimi ve Behiç Ak'ın Tavşan Dişli 
Bir Gözlemcinin Notları'nda sevgi. Millî Eğitim Dergisi, 49(226), 185-204.

Baki, Y. (2019). Ortaokul Türkçe ders kitaplarındaki metinlerin değer aktarımı açısından incelenmesi. Değerler Ĕ̈itimi Dergisi, 17(37), 109-146. https://doi.org/10.34234/ded.460042

Baran Yir, B. (2019). Bilgin Adalı'nın eserlerinin değerler eğitimi açısından incelenmesi (Yüksek Lisans Tezi). Bülent Ecevit Üniversitesi, Sosyal Bilimler Enstitüsü, Zonguldak.

Batur, Z. ve Yücel, Z. (2012). Ahmet Efe'nin çocuk hikâyelerinde değerler eğitimi ve hikâyelerin Türkçe eğitime katkısı. Turkish Studies, 7(4), 1031-1049.

Behrengi, S. (2019). Bir şeftali bin şeftali. Parıltı Yayıncılık.

Behrengi, S. (2019). Kel güvercinci. Parıltı Yayınc1lık.

Behrengi, S. (2019). Sevgi masall. Parıltı Yayıncılık.

Belet Boyac1, Ş. D., Güner, M. ve Babadağ, G. (2017). "Dünyada başka şekilde yaşamak da mümkün mü?" Değer eğitiminde "Küçük Kara Balık" örneği. Eğitimde Nitel Araştırmalar Dergisi - Journal of Qualitative Research in Education, 5(3), 172-194.

Binyıl Şahin, N. (2019). Sabahattin Ali'nin eserlerinde değerler eğitimi (Yüksek Lisans Tezi). Gazi Üniversitesi, Eğitim Bilimleri Enstitüsü, Ankara.

Boydak Özan, M. ve Öztürk, E. (2018). Öğretmenlerin değer yargılarının okul paydaşları üzerindeki etkisine yönelik yönetici görüşleri. İnönü Üniversitesi Eğitim Bilimleri Enstitüsü Dergisi, 5(10), 18-32.

Bulut, K. (2021). Ayla Kutlu'nun 'Merhaba Sevgi' adlı çocuk romanının değerler eğitimi ve on kök değer açısından incelenmesi. Mehmet Akif Ersoy Üniversitesi Ĕ̈itim Fakültesi Dergisi, (57), 248-272.

Calp, Ş. ve Calp, M. (2019, 19-21 Nisan). Küçük Kara Balık ve Küçük Prens kitaplarının Sosyal Bilgiler Öğretim Programı'ndaki temel beceriler, değerler ve 4. sinıf kazanımları açısından incelenmesi. 3. International Symposium on Innovative Approaches in Scientific Studies (ISAS) (pp.61-69), Ankara, Türkiye.

Demir, N. (2019). Değerler eğitimi açısından Necip Fazıl Kısakürek'e ait "Çile" adll aserde kök değerlerin incelenmesi (Yüksek Lisans Tezi). Atatürk Üniversitesi, Sosyal Bilimler Enstitüsü, Erzurum.

Devellioğlu, F. (2005). Osmanlıca- Türkçe Ansiklopedik Lugat. Aydın Kitapevi Yayınları. 
Doğaner, M. (2021). Halit Ziya Uşaklıgil'in romanlarında değerler eğitimi (Yüksek Lisans Tezi). Dokuz Eylül Üniversitesi, Eğitim Bilimleri Enstitüsü, İzmir.

Eker, C. ve Yıldırım, K. (2017). Değerler eğitimi açısından Ziya Gökalp'e ait "Altın Iş̧1k" adlı eserin incelenmesi. Karaelmas Eğitim Bilimleri Dergisi, 5(1), 30-38.

Ekşi, H. (2003). Temel insani değerlerin kazandırılmasında bir yaklaşım: Karakter eğitimi programları. Değerler Ĕ̈itimi Dergisi, 1(1), 79-96.

Erdal, K. (2009). Eğitim değerleri açısından çocuk kitapları. Akademik Bakış Uluslararası Hakemli Sosyal Bilimler E-Dergisi, 17, 1-18.

Ergül Özkul, Z. (2019). Haldun Taner'in öykülerinde tespit edilen değerlerin Türkçe Öğretim Programında (1-8. Sinıf) yer alan kök değerlerle uyumu (Yüksek Lisans Tezi). S1tkı Koçman Üniversitesi, Eğitim Bilimleri Enstitüsü, Muğla.

Erkan, G. ve Aykaç, M. (2014). Samet Behrengi’nin kitaplarıyla kurgulanan yaratıcı drama etkinliklerinin öğrencilerin yazma becerisi ve tutumlarına etkisi. Uluslararası Sosyal Araştırmalar Dergisi, 7(31), 600-610.

Erol, E. E. (2014). Tarık Buğra'nın hikâyelerinin değerler eğitimi açısından incelenmesi (Yüksek Lisans Tezi). Yüzüncü Yıl Üniversitesi, Eğitim Bilimleri Enstitüsü, Van.

Gümüş, S. (2017). Değerler eğitimi bağlamında Aytül Akal'ın çocuk romanlarının analizi (Yüksek Lisans Tezi). Marmara Üniversitesi, Eğitim Bilimleri Enstitüsü, İstanbul.

Karagöz, B. (2017). Naki Tezel'in Türk Masalları adlı kitabının değerler açısından analizi. Ana Dili Eğitimi Dergisi, 5(3), 534-556. https://doi. org/10.16916/aded.331362

Karasar, N. (1998). Bilimsel araştırma yöntemi. Nobel Yayınları.

Karatay, H. (2007, 10-15 Eylül). Değer aktarımı açısından yerli ve yabancı çocuk edebiyatı ürünleri. 38. ICANAS, Uluslararası Asya ve Kuzey Afrika Çalışmaları Kongresi, Ankara, Türkiye.

Kasapoğlu, H. (2013). Okulda değer eğitimi ve hikâyeler. Millî Eğitim Dergisi, 43(198), 97-109.

Kumbasar, E. (2011). Muzaffer İzgü'nün romanlarının değerler eğitimi açısından incelenmesi (Yüksek Lisans Tezi). Karadeniz Teknik Üniversitesi, Eğitim Bilimleri Enstitüsü, Trabzon. 
Kuru, H. ve Keklik, S. (2016). Ayşe Yamaç'ın çocuk romanlarının değerler eğitimi açısından incelenmesi. Igdir University Journal of Social Sciences, 10, 217-237.

MEB.(2020, 1 Ekim).Değerler eğitimi yönergesi. http://mebk12.meb.gov. tr/meb_iys_dosyalar/34/39/749197/dosyalar/2015_02/09093609_degerleregitimi.pdf

Millî Eğitim Temel Kanunu, Kanun No: 1739, 24.06.1973/14574.

Otmar, Ö. ve Erdem, A. (2019). Yalvaç Ural'ın çocuk edebiyatı eserlerinde hayvan sevgisi değeri. Değerler Ĕgitimi Dergisi, 17(37), 7-34.

Özay, Ş. (2019). Çocuk edebiyatı açısından Ülker Köksal'ın romanlarında değerler eğitimi (Yüksek Lisans Tezi). Kocatepe Üniversitesi, Sosyal Bilimler Enstitüsü, Afyon.

Özbaşı, S. (2020). Türkçe dersi öğretim programındaki kök değerlerçerçevesinde Aytül Akal masallarının incelenmesi. IBAD Sosyal Bilimler Dergisi, (8), 178-192. https://doi.org/10.21733/ibad.715132

Senek, S. (2018). Aytül Akal'ın masallarının değerler eğitimi açısından incelenmesi (Yüksek Lisans Tezi). Akdeniz Üniversitesi, Eğitim Bilimleri Enstitüsü, Antalya.

Topbaş, A. (2015). Sema Maraşlı'nın masallarının değerler eğitimi açısından incelenmesi (Yüksek Lisans Tezi). Necmettin Erbakan Üniversitesi, Eğitim Bilimleri Enstitüsü, Konya.

TDK (2005). Türkçe Sözlük, Türk Dil Kurumu Yayınları.

TDK (2020, 13 Kasım). Güncel Türkçe Sözlük. https://sozluk.gov.tr/

Talim ve Terbiye Kurulu Başkanlığı [TTKB]. (2020, 3 Aralık). Müfredatta yenileme ve değişiklik çalışmalarımız üzerine. http://ttkb.meb.gov.tr/meb_ iys_dosyalar/2017_07/18160003_basin_aciklamasi-program.pdf

Tozlu, N. ve Yüce, B. N. (2020). Hamdi Ülker'in eserlerinin kök değerler açısıdan incelenmesi. RumeliDe Dil ve Edebiyat Araştırmaları Dergisi, (21), 575-597. https://doi.org/10.29000/rumelide.843597

Ulusoy, K. ve Dilmaç, B. (2016). Değerler eğitimi (4. baskı). Pegem Akademi.

Utku, İ. E. (2020). Mustafa Necati Sepetçioğlu'nun eserlerinin değerler eğitimi bağlaminda incelenmesi (Yüksek Lisans Tezi). Akdeniz Üniversitesi, Eğitim Bilimleri Enstitüsü, Antalya.

Yeniay, S. (2019). Behiç Ak'ın hikâyelerinin değerler eğitimi açısından incelenmesi (Yüksek Lisans Tezi). Necmettin Erbakan Üniversitesi, Eğitim Bilimleri Enstitüsü, Konya. 
Yıldırım, A. ve Şimşek, H. (2018). Sosyal Bilimlerde Nitel Araştırma Yöntemleri (11. Bask1). Seçkin Yayıncılık.

Yılmaz, A. (2018). Değerler eğitimi bağlamında Aytül Akal'in çocuk romanları (Yüksek Lisans Tezi). Hacı Bektaş Veli Üniversitesi, Sosyal Bilimler Enstitüsü, Nevşehir. 
Extended Abstract

\section{An Investigation of Samed Behrengi's Three Works: Tale of Love, One Peach Thousand Peaches and Bald Pigeon in Terms of Root Values}

Mehrali CALP, Corresponding Author, Associate Professor.

Ağrı İbrahim Çeçen University, Faculty of Education, Ağrı / Turkey.

mcalp@agri.edu.tr

https://orcid.org/0000-0002-2261-4893

Cezmi KAPLAN, Teacher.

Republic of Turkey Ministry of National Education, Bitlis / Turkey.

cezmikaplan13@hotmail.com

https://orcid.org/0000-0003-1355-6035

Article Type: Research Article

https://doi.org/10.34234/ded.895236

Received Date: 09.04 .2021

Accepted Date: 12.12 .2021

Published Date: 25.12.2021

\section{Introduction}

In the rapidly developing and changing world, the aim of education should not be just to transfer academic knowledge and skills. Education is an important process that starts in the family environment and continues under the roof of the school and prepares people for life. The word education, in the Turkish Dictionary (TDK, 2005), is defined as helping children and young people acquire the necessary knowledge, skills and understandings to take their place in social life, and help them develop their personalities, directly or indirectly, inside or outside the school. Although raising individuals who are equipped with cognitive skills is one of the main goals of education, the education of values that serve 
to transfer the culture that provides social cohesion and keeps the society alive is also one of the goals of education. Values are important energy sources that make people's lives meaningful and move people to action. Since values are built on cultural elements, they are transferred from generation to generation through culture and ensure the continuity of each other (Akbaba Altun, 2003). For individual to have healthy future they are supposed to acquire the emotions, behaviors and rules that constitute the society a, which also affect the development of the humanist virtues a and perceptions (Ulusoy \& Dilmaç, 2016). For this reason, educational institutions should not only equip individuals with academic success, but also strive to help the individual to have a healthy personality and adapt to social values. Schools, where formal education is carried out in a planned and programmed way, are considered the most suitable areas for the transfer of morals to generations. Child's learning which is influenced by the teacher, who play a fundamental role, after the family environment and close environment of the child has great duties in value transfer since he or she is responsible for planning and implementing educational and training programs (Karatay 2007). It should not be forgotten that the best way to teach values in the school environment is to have those values first and then to be a role model (Kasapoğlu, 2013). Teachers, who are role models for their students, should provide their students with the opportunity to experience and practice values. In this way, values education takes place more easily.

All verbal and written sources that can appeal to children's feelings and thoughts can be used in values education (Kasapoğlu, 2013). Books prepared by considering values and suitable for the age and developmental level of students positively affect values education. Literary works, which has relevance to children own world and offer them some life experiences, help children acquire values naturally in the education age. While the heroes in literary works have an important place in the selection of role models for children, the values included in literary works are also important (Gümüş, 2017). Therefore, regardless of the genre, the subjects, characters and narrative techniques used in children's literature products; should reflect the colorful and innocent world of children in a positive way, and should aim to equip them with some appropriate behavior patterns and values (Arseven, 2005). Childhood is a very important period for personality development. During this period, the child looks for a role and model. This can sometimes be a friend, sometimes a teacher, and sometimes a hero of the work. Children sometimes face the problems of life with the characters of the work and find solutions to them. In this way, he acquires social values 
without even being aware of it. For this reason, the reading materials should be chosen well.

\section{Method}

In this study, scanning model, one of the qualitative research methods, was used. Scan models are models designed to describe events or situations. The definition of the subject or situation depends on its own conditions and current situation (Karasar, 1998).

In this study, in which qualitative research method was used, document analysis technique was used as a data collection tool. For this purpose, the stories written by Samed Behrengi were determined within the scope of literature review. The names of the specified stories were written, their sequence number was given, and 3 stories were determined by systematic sampling method. These stories names are: "Love Tale", "One Peach Thousand Peach" and "Bald Pigeon" and were obtained from Parıltı Publications. Then, theses, articles, periodicals, Turkish lesson curriculum, that contain the root values and related to subject of the research, were examined.

Within the scope of the study, Samed Behrengi's stories "Love Tale", "One Peach Thousand Peach" and "Bald Pigeon" were read several times in detail by the researchers. Values included in the 2019 Turkish Course Curriculum are defined as:

justice, which means "rights and compliance with the law, observance of rights" (TDK, 2021); friendship which addressed through terms and concept s related to "friend, loved, trusted, close friend; companion, well-connected person, each one of those who love each other" (Albayrak, 2004); while honesty taken in the sense of truth. Self-control (TDK, 2021), which means "controlling and restricting one's reactions, behaviors or tendency to turn to another goal in order to achieve a more important goal, self-control." Patience, is used in the sense of "patient, enduring, waiting without haste, clenching his teeth" (Devellioğlu, 2005); Respect, which means "the feeling of love, respect, dignity that causes to be careful, attentive and measured towards someone or something because of its value, status, old age, usefulness, and sanctity" (TDK, 2021); Love, which is defined as "the emotion that leads a person to show close interest and devotion towards something or someone" (TDK, 2021); "Responsibility used in the sense of responsibility, is defined as (TDK, 2021) being accountable for one's 
own behavior or the consequences of any event that falls within its jurisdiction; in patriotic sense it means the feeling of love for one's homeland or making sacrifices for one's homeland; Helpfulness, which is defined by Aktepe as an important emotion that strengthens the bond between individuals of the society, makes up for the deficiencies and fills the gaps (2010)

based on these root values, the values in each of the works were determined by the document analysis method. Values found in the stories were classified and their frequency status was determined. Ten root values, which were directly or implicitly processed by the author, were identified, cited in the findings section, and their frequencies in each work shown in tables.

In this research, Samed Behrengi's "Tale of Love", "One Peach Thousand Peach" and "Bald Pigeon" stories were subjected to descriptive analysis in terms of the frequency in the usage of root values. The main purpose of the descriptive analysis is to reach the concepts and relationships that can explain the collected data, and to summarize and interpret the obtained data in the light of predetermined themes (Yıldırım \& Şimşek, 2018).

In the study, all works were scanned in terms of the ten root values in the 2019 Turkish Language Curriculum. Examples of root values in the works are shown with direct quotations. Even if there are repetitions in different parts of the works, the value expressed was added to the findings. In finding section the names of the works that are included are abbreviated and shown together with the page number. While analyzing the data, the purpose and questions of the research were taken into consideration. After the analysis made by the researchers, the observation and opinions of experts, one ranks as associate professor and one with doctoral degree were consulted. Thus, recommendations were received regarding the compatibility between the values corresponding to the codes and necessary arrangements were made.

\section{Findings}

A total of 102 values have been identified, 43 in the story named "Tale of Love", 30 in the story "One Peach Thousand Peaches", and 29 in the story named "Bald Pigeon".

It has been observed that the love value is mostly used in the stories of Samed Behrengi. It has been determined that importance was assigned to values of patience, justice, responsibility, honesty, helpfulness, friendship, respect, self-control after the value of love. Patriotic value was absent in all three works. 


\section{Discussion, Conclusion, Suggestions}

Many written, verbal or visual materials are used in the education of values that shape children's lives and integrate them with society. Literary works are at the forefront of the written materials used in values education. Emotions, thoughts, social values and behavior patterns that are desired to be conveyed to children can be transferred more effectively and permanently through literary works (Erdal, 2009). It is possible to convey values through literary works that contain countless knowledge and sense of value-appreciation. Based on this context, in this study, Samed Behrengi's works titled "Tale of Love", "One Peach Thousand Peach" and "Bald Pigeon" were examined, taking into account the root values contained in the 2019 Turkish Curriculum.

There are many studies in the literature similar to this study, which examines the works where values are conveyed explicitly or implicitly. In the studies conducted by Yeniay (2019), Demir (2019) and Kumbasar (2011); it has been found that the values are given directly in some parts while they conveyed through intuition in other parts. These studies coincide with this study in which Samed Behrengi's works are examined.

In most of the studies on root values and in Samed Behrengi's works, it has been determined that the most common value is the value of love (46). These results were obtained by Boyac1 et al. (2017) and the studies of Calp and Calp (2019).

In the study of Tozlu and Yüce (2020) in which Hamdi Ülker's works were examined in terms of root values, the value of love was found to be the most frequent. Likewise, in the study by Bulut (2021), in which Ayla Kutlu's children's novel "Hello Sevgi" was examined in terms of values related to education and ten root values, the values of love, honesty, benevolence, responsibility and respect were found to be the most frequent. It has been determined that the value of love is the most frequently used value in many works examined in terms of values education in the literature (Abac1, 2018; Aydoğdu and Alkan, 2020; Baran Yir, 2019; Batur and Yücel 2012; Binyıl Şahin, 2019; Doğaner, 2021; Eker and Y1ldırım, 2017; Ergül Özkul, 2019; Erol, 2014; Gümüş, 2017; Karagöz, 2017; Kumbasar, 2011; Kuru and Keklik 2016; Otmar and Erdem, 2019; Özay, 2019; Özbaş1, 2020; Senek, 2018; Topbaş, 2015; Utku, 2020; Y1lmaz, 2018).

In the sentences that included the value of justice, issues like injustice and inequality are emphasized. The value of justice has been conveyed through sit- 
uations where injustice and inequality exist. In the study of Binyıl Şahin (2019), it was seen that the value of justice was tried to delivered in a similar way.

Patriotism, which is one of the ten root values, has never been found in Samed Behrengi's three works. In the study conducted by Karagöz (2017), it was stated that the value of patriotism is one of the least mentioned values ( 3 times). In the study conducted by Kumbasar (2011), it was determined that the value of patriotism was not adequately addressed. The studies in question show similarities in terms of the frequency of the value of patriotism.

\section{Suggestions}

- These three works, which have many issues that can contribute to the transfer of ten root values, can be used in values education for primary school children.

- The story "Bald Pigeon" which contains values such as: love, patience, justice, friendship, benevolence, responsibility; Justice, honesty, love, responsibility, patience; can be recommended as a useful educational material that can be used in activities and utilized directly or indirectly in the transfer of the root values of love, justice, benevolence, responsibility and honesty.

- For values related to education, Samed Behrengi's analyzed works can be used as sample text in school books.

- Along with analysis on 3 works of Samed Behrengi, other works could be included to expand the scope of root value analysis.

Etik Beyan / Ethical Statement: Bu çalışmanın hazırlanma sürecinde bilimsel ve etik ilkelere uyulduğu ve yararlanılan tüm çalışmaların kaynakçada belirtildiği beyan olunur. / It is declared that scientific and ethical principles have been followed while carrying out and writing this study and that all the sources used have been properly cited.

Finansman / Funding: Yazarlar, bu araştırmayı desteklemek için herhangi bir dış fon almadıklarını kabul ederler. / The authors acknowledge that they recevied no external funding in support of this research.

Yazar (lar) / Author (s): Mehrali CALP, Cezmi KAPLAN

Yazar Katkıları / Author Contributions: Mehrali CALP (\%50), Cezmi KAPLAN (\%50)

Çıkar Çatışması / Competing Interests: Yazarlar, çıkar çatışması olmadığını beyan ederler. / The authors declare that they have no competing interests. 